\title{
PENGARUH VEGETASI DALAM MEREDAM TINGKAT KEBISINGAN LALU LINTAS JALAN RAYA DI KAWASAN TAMAN WISATA ALAM (TWA) PUNTI KAYU PALEMBANG
}

\author{
Yosieguspa \\ Sriwijaya Program Studi Pengelolaan Lingkungan \\ Fakultas Pengelolaan Lingkungan Pascasarjana Univ. Sriwijaya, Palembang \\ Email : Kitty.ochie@yahoo.co.id
}

\begin{abstract}
ABSTRAK
Telah dilakukan penelitian tentang pengaruh vegetasi terhadap tingkat kebisingan. Sumber kebisingan berasal dari suara kendaraan yang melintas di jalan raya tersebut. Alat yang digunakan untuk meredam tingkat kebisingan dalam penelitian ini adalah Sound Level Meter (SLM). Posisi SLM kejalan raya diatur dengan jarak $20 \mathrm{~m}, 40 \mathrm{~m}$, dan $60 \mathrm{~m}$. Pengaruh waktu selama satu hari mulai pukul 07.00 sampai 17.00 terhadap kebisingan dilakukan untuk mendapatkan profil (pola) tingkat kebisingan selama satu hari di jalan raya Kol. H. Barlian Km. 07 Palermbang. Dari hasil penelitian ini didapat bahwa parameter vegetasi yang berperan dalam meredam vegetasi yaitu kerapatan vegetasi dan tinggi batang bebas cabang. Dimana hasil penelitian menunjukkan bahwa pengaruh kebisingin $(Y)$ terhadap parameter vegetasi yaitu kerapatan vegetasi $\left(X_{1}\right)$ dan tinggi batang bebas cabang $\left(\mathrm{X}_{2}\right)$ terlihat pada persamaan $Y=58.4$ - $7.6 X_{1}-1.186 X_{2}$. Parameter vegetasi mempunyai kontribusi besar terhadap pengurangan intensitas kebisingan adalah kerapatan vegetasi yaitu mampu mengurangi kebisingan $7.6 \mathrm{~dB}(A)$ dan tinggi batang bebas cabang dapat mengurangi kebisingan sebesar $1.186 \mathrm{~dB}(\mathrm{~A})$.

Kata kunci : Kebisingan, vegetasi, kendaraan dan jarak

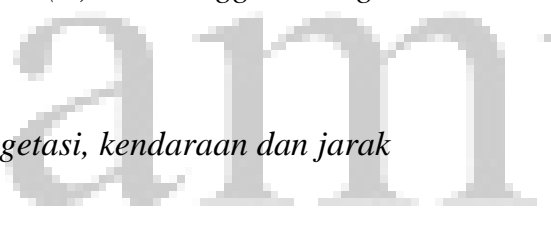

ABSTRACT
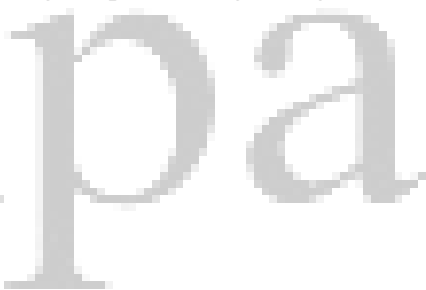

The influence of vegetation on the noise level research has done. The source of the noise comes from the sound of vehicles passing on the highway. The instrument used to dampen the noise level in this study was a Sound Level Meter (SLM). Position of the SLM kejalan Kingdom administered with a distance of $20 \mathrm{~m}, 40 \mathrm{~m}, 60 \mathrm{~m}$ and the influence of time during one day from 07.00 till 17.00 to done to get noise profile (pattern) the noise level during a single day in the Kol. H. Barlian km. 07 Palermbang. From the results of this research were obtained that vegetation parameters that play a role in suppressing the vegetation density and height the vegetation-free stem branches. Where the results of the study showed that the influence of the kebisingin $(Y)$ against the density of vegetation the vegetation parameter $(X 1)$ and tall trunk branch $(x 2)$-free look at the equation Y 58.4-7.6 X 1-X 2 1.186. Vegetation parameters have a major contribution to the reduction of the intensity of the noise is the density of the vegetation that is capable of reducing noise $7.6 \mathrm{~dB}(A)$ and height rods-free branch can reduce noise by $1.186 \mathrm{~dB}(\mathrm{~A})$.
\end{abstract}




\section{PENDAHULUAN}

Pembangunan kota pada masa lalu mempunyai kecenderungan untuk meminimalkan Ruang Terbuka Hijau (RTH) dan menghilangkan wajah alam. Lahan-lahan banyak yang dialihfungsikan menjadi pemukiman, perkotaan, industri, tempat-tempat rekreasi, dan lain-lain.Fungsi hijau dalam RTH pada suatu kawasan sebagai paru - paru kota tempat berlangsungnya fungsi daur ulang antara gas $\mathrm{CO}_{2}$ dan $\mathrm{O}_{2}$, hasil fotosintesis khususnya pada dedaunan.RTH dalam bentuk hutan kota dengan luas $25 \mathrm{Ha}$ dalam satu tahun mampu menghasilkan 1 ton $\mathrm{O}_{2}$ yang dilepas ke udara.

Kebisingan merupakan bentuk suara yang tidak dikehendaki karena dianggap mengganggu. Aktivitas lalu lintas adalah sumber kebisingan di kawasan TWA Punti Kayu yang setiap harinya dialami masyarakat kota tersebut. Berdasarkan SK Menteri Kehutanan tanggal 7 Oktober No 9273/Kpts-II/2002 Taman Wisata Alam (TWA) Punti Kayu Palembang adalah taman yang menyajikan hiburan bernuansa hutan wisata alam atau hutan konservasi. TWA Punti Kayu juga berfungsi melengkapi wisata di kota Palembang. Dengan luas sekitar 50 ha, hutan ini mulanya ditetapkan sebagai hutan lindung, Sebagian arealnya sudah menjadi zona wisata terbuka.TWA Punti Kayu, berlokasi di Jl. Kol. H. Barlian, Kecamatan Sukarami berjarak sekitar $7 \mathrm{~km}$ dari pusat kota. Potensi TWA Punti Kayu berupa panorama hutan pinus (Pinus Mercussi), Akasia (Acacia Mangium), Mahoni (Switenia Swageri), Talog (Muntingia calabura) dan Pulai (Alstonia Granensis).Dijelaskan dalam penelitian sebelumnya (Slamet, 2003) bahwa penghijauan perkotaan di Indonesia memiliki fungsi dan peran penting antara lain : sebagai paru - paru kota, pengatur iklim mikro, estetika, ekologis, protektif, hygiene, dan edukasi. Beberapa fungsi hutan kota lainnya yang penting bagi kehidupan manusia diantaranya, yaitu : pelestarian plasma nutfah, penahan dan penyaring debu, mengatasi instrusi air laut dan abrasi, penahan angin, penghasil oksigen, dan peredam kebisingan (Huboyo dan Sumiati, 2008).
Pohon dapat meredam suara dan menyerap kebisingan sampai dengan 95\% dengan cara mengabsorbsi gelombang suara oleh daun, cabang dan ranting. Jenis vegetasi yang efektif untuk meredam suara adalah yang mempunyai tajuk yang tebal dengan daun yang rindang. Berbagai jenis tanaman dengan berbagai strata yang cukup tinggi akan dapat mengurangi kebisingan (Kusmana dan Istomo, 1995).Kayu mempunyai sifat dalam menyerap dan memantulkan bunyi. Kayu terdiri atas sel-sel besar dan kecil yang satu sama lain tumbuh lekat, sehingga ronggarongga kayu banyak mengubah energi bunyi menjadi energi gesekan/kalor (Aisah dkk, 2002). Tetapi kayu cukup padat dan elastis untuk berfungsi sebagai membrane resonator yang memungkinkan pemantulan bunyi. Kombinasi daya serap dan daya resonansi serta penghalang bunyi yang begitu bagus tidak terdapat pada bahanbahan organik lain dan logam (Mangunwijaya, 1988). Menurut pendapat Dumanauw (1990), sifat kayu terhadap suara berhubungan dengan sifat elastisitas kayu.Sifat ini penting ketika diaplikasikan untuk alat musik dan kontruksi bangunan.

Vegetasi mampu menyerap dan menghalangi bising sehingga membuat lingkungan lebih nyaman.Tingkat penyerapan - kebisingan oleh vegetasi tergantung pada jenis vegetasi, kepadatan, kerimbunan, lokasi dan frekuensi suara (Umiati, 2011).Jenis vegetasi yang digunakan untuk penghalang kebisingan harus memiliki kerimbunan dan kerapatan daun yang cukup dan merata mulai dari permukaan tanah hingga ketinggian yang diharapkan. Untuk itu perlu diatur suatu kombinasi antara vegetasi penutup tanah, perdu dan pohon atau kombinasi dengan vegetasi lainnya sehingga efek penghalang menjadi optimum. Vegetasi yang dapat digunakan adalah a)Penutup tanah: rumput, leguminosae; b) Perdu: bambu pringgodani, soka, teh-tehan, kekaretan; c) Pohon: akasia, johar (casia siamea) dan jenis pohon lain yang rimbun dengan cabang rendah.

Penghalang dengan vegetasi harus cukup tinggi untuk dapat memotong garis 
perambatan gelombang suara dari sumber ke penerima.Kedalaman (ketebalan) vegetasi serta persentase kerimbunan daun disesuaikan dengan jenis vegetasi yang digunakan untuk penghalang.

Vegetasi dapat meredam kebisingan tergantung pada spesies vegetasi, tinggi vegetasi, kerapatan atau jarak tumbuh vegetasi, faktor iklim (angin, suhu, dan kelembaban udara).Tingkat peredaman ini juga tergantung pada properti dari suara yaitu tipe, asal, tingkat desibel, dan intensitas suara (Wibisono, 2008).

Tingkat kebisingan yang dapat diredam oleh vegetasi juga dipengaruhi oleh intensitas, frekuensi, dan arah bunyi (Meilani, 2002).Kerapatan dan ketebalan vegetasi dapat menurunkan tingkat kebisingan, tanpa kerapatan vegetasi penurunan kebisingan tidak terjadi dimana dapat menimbulkan dampak negatif terhadap psikologi penerima (FHWA, 1980).

Hutan kota berfungsi mengurangi kebisingan. Selain menghalangi gelombang suara juga menghalangi sumber suara.Gelombang suara di absorbsi oleh daun, cabang, ranting dan pohon (Irwan, 1994). Penggunaan vegetasi untuk menyaring kebisingan tidak akan efektif apabila tidak memperhatikan ukuran dan kepadatannya. Hutan dapat menyerap sekitar 6-8 desibel per 30 meter.Kerapatan vegetasi lebih penting dari pada spesies vegetasi untuk meredam kebisingan (Irwan, 1994).Lokasi sampel hutan kota yang diteliti memiliki jarak dari sumber kebisingan dengan daerah depan vegetasi yang berbeda - beda. Hutan kota bentuk jalur hijau memiliki jarak terdekat antara daerah depan vegetasi dengan sumber kebisingan dibandingkan dengan hutan kota bentuk menyebar dan mengelompok. Jarak antara sumber kebisingan dengan daerah depan vegetasi merupakan lahan terbuka tanpa vegetasi. Penurunan tingkat kebisingan terjadi pada jarak yang semakin jauh dari sumber kebisingan, tetapi tidak seefektif menggunakan barrier vegetasi. Kerapatan vegetasi akan efektif mereduksi kebisingan padajarak yang dekat dengan sumber kebisingannya. Untuk mendapatkan hasil yang optimum dalam mereduksi kebisingan, jajaran semak dan pohon seharusnya ditanam dekat pusat kebisingan (Irwan, 2008).

Faktor lingkungan yang diduga dapat mempengaruhi besarnya nilai reduksi kebisingan juga diukur bersamaan dengan pengukuran kebisingan masing - masing lokasi sampel.Faktor lingkungan yang diukur bersamaan pada saat pengukuran tingkat kebisingan adalah suhu, kelembapan dan kecepatan serta arah angin. Nilai tersebut diukur untuk mengetahui adanya hubungan antara faktor lingkungan dengan kemampuan reduksi kebisingan dan sebagai penunjang hasil hubungan antara hutan kota dengan reduksi kebisingan. Pengukuran suhu dan kelembapan dilakukan secara bersamaan dengan pengukuran tingkat kebisingan pada masing - masing lokasi. Faktor - faktor lingkungan tidak dapat secara langsung berpengaruh terhadap besar kecilnya nilai reduksi kebisingan. Faktor tersebut erat kaitannya dengan perambatan bunyi atau dengan parameter vegetasi yang membangun hutan kota tersebut. Kerapatan vegetasi misalnya, semakin rapat tanaman dalam suatu plot akan memberikan penurunan suhu dibanding lahan terbuka (Irwan, 1994). Bagian pohon yang mampu meredam kebisingan meliputi batang, daun, ranting, dan cabang. Daun, ranting, dan cabang berada pada tempat yang lebih tinggi dari ketinggian pengukuran kebisingan sehingga kurang diketahui keefektifitasannya dalam meredam bunyi yang ada. Perlu dilakukan pengukuran tingkat kebisingan pada ketinggian yang lebih tinggi dari penelitian ini agar dapat diketahui tingkat kebisingan yang terjadi setelah melewati cabang, ranting, dan daun.Kondisi tersebut melatarbelakangi peneliti dalam menyusun studi ini guna menganalisis sejauh mana pengaruh jarak terhadap tingkat peredaman kebisingan dan bagaimana pengaruh kerapatan vegetasi dan tinggi batang bebas cabang terhadap tingkat peredam kebisingan. 


\section{METODOLOGI PENELITIAN}

\section{Teknik Pengumpulan Data}

a. Survei lokasi

Survei lokasi dilakukan dengan menelusuri daerah sekitar TWA Punti Kayu Palembang. Penelusuran ini dimaksudkan untuk mencari lokasi yang layak digunakan sebagai area kajian termasuk juga untuk memilih lokasi yang akan digunakan sebagai kontrol, yang dimaksud dengan area kajian adalah area dengan kerapatan vegetasi yang bervariasi.

Kriteria yang dapat digunakan sebagai kontrol adalah lahan yang tidak terdapat vegetasi terbuka yang terdapat di sekitar jalan raya TWA Punti Kayu Palembang.Setelah ditentukan area kontrol dan area kajian yang sesuai, dilakukan pengecekan waktu aktivitas jalan raya, pengecekan tingkat aktivitas ini digunakan untuk menentukan sumber kebisingan yang melewati area kajian.

b. Persiapan Penelitian

- Persiapan Alat

- Identifikasi sumber kebisingan

- Pengumpulan data sekunder

c. Penentuan lokasi sampling

- Terdapat 6 titik sampling sebagai plot kuadran

- Titik sampling dibagi berdasarkan daerah kajian dan daerah kontrol

- Pengukuran koordinat di setiap titik sampling

d. Pelaksanaan penelitian

- Variabel tempat berupa pengukuran dilakukan pada masing - masing plot kuadran

- Variabel waktu yaitu pada hari kerja sesuai KepMen LH 48/1996

e. Pengukuran Kebisingan

- Pengukuran tingkat kebisingan menggunakan SLM

- Pengukuran tingkat kebisingan dilakukan pada masing - masing titik sampling dan dilakukan selama 10 menit

- Pengukuran kebisingan dilakukan pada hari kerja dalam range waktu tertentu (sesuai dengan KepMen LH 48/1996)
- Pemilihan hari pada senin (awal minggu) kamis ( tengah minggu) dan sabtu (akhir minggu) untuk mewakili kepadatan lalun lintas sepanjang minggu.

f. Pengukuran jarak, kerapatan vegetasi dan tinggi batang bebas cabang

1. Di daerah kontrol ditempatkan plot kuadran berukuran $20 \times 20 \mathrm{~m}$ sebanyak 3 plot. Pengukuran intensitas kebisingan dilakukan pada titik dengan jarak $20 \mathrm{~m}, 40 \mathrm{~m}$ dan $60 \mathrm{~m}$ dari aktivitas jalan raya.

2. Di daerah kajian juga ditempatkan plot kuadran masing - masing berukuran berukuran $20 \mathrm{~m}$ x $20 \mathrm{~m}$ sebanyak 3 plot, pengukuran intensitas kebisingan dibuat berlapis pada jarak $20 \mathrm{~m}, 40 \mathrm{~m}$ dan $60 \mathrm{~m}$ dari aktivitas jalan raya.

3. Di daerah kajian vegetasi yang berada di setiap plot dilakukan pengukuran tinggi batang lepas cabang.

4. Menghitung jumlah masing masing jenis vegetasi dalam tiap plot.

g. Arah angin dan kecepatan angin ditentukan dengan bantuan alat Anemometer dengan pengukuran kecepatan angin pada ketinggian 2 meter, 6 meter dan 10 meter, sumber data diperoleh dari BMKG Palembang.

h. Data lain yang diperlukan suhu, kelembapan dan kecepatan angin.

\section{HASIL DAN PEMBAHASAN}

Dari data pengukuran intensitas kebisingan di daerah kontrol untuk hari Senin, Kamis dan Sabtu terjadi pengurangan intensitas kebisingan karena faktor jarak. Untuk intensitas kebisingan yang terbesar terjadi pada hari Senin dapat dikarenakan aktivitas kerja dimulai dimana dapat mewakili hari sibuk sehingga menyebabkan aktivitas tinggi untuk lalu lintas dengan nilai

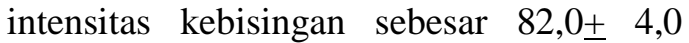
$\mathrm{d}(\mathrm{BA})$, sedangkan penurunan kebisingan terbesar mewakili hari sibuk terjadi pada hari Kamis dengan jarak 20 meter ketiga $(60 \mathrm{~m})$ yaitu dengan pengurangan intensitas 
kebisingan sebesar 18,1 dB(A). Sementara untuk hari Sabtu mewakili hari akhir pekan atau libur kebisingan terbesar terjadi pada Pukul 10.00 sebesar 78,7 $\pm 5,8 \mathrm{~dB}(\mathrm{~A})$ dapat disebabkan karena hari libur aktivitas arus kendaraan pun meningkat, sedangkan pengurangan intensitas kebisingan sebesar juga terjadi pada Pukul 10.00 dengan jarak 20 meter ketiga $(60 \mathrm{~m})$ yaitu dengan pengurangan intensitas kebisingan sebesar $20,8 \mathrm{~dB}(\mathrm{~A})$.

Tabel 1. Nilai intensitas kebisingan di area kontrol dB(A) (Hari Senin)

\begin{tabular}{cccc}
\hline \multirow{2}{*}{$\begin{array}{c}\text { Hari } \\
\text { senin }\end{array}$ Waktu) } & \multicolumn{3}{c}{$\begin{array}{c}\text { Intensitas kebisingan rata- rata pada } \\
\text { berbagai jarak pengukuran dB(A) }\end{array}$} \\
\cline { 2 - 4 } & $\begin{array}{c}\mathbf{2 0} \mathbf{~ m} \\
\text { (Plot 1) }\end{array}$ & $\begin{array}{c}\mathbf{4 0} \mathbf{~ m} \\
\text { (Plot II) }\end{array}$ & $\begin{array}{c}\mathbf{6 0} \mathbf{~ m} \\
\text { (Plot III) }\end{array}$ \\
\hline 07.00 & $80,3 \pm 5,8$ & $76,1 \pm 2,4$ & $68,5 \pm 3,2$ \\
\hline 10.00 & $82,0 \pm 4,0$ & $72,3 \pm 2,9$ & $68,6 \pm 2,4$ \\
\hline 17.00 & $76,6 \pm 3,0$ & $67,3 \pm 4,4$ & $63,2 \pm 4,9$ \\
\hline
\end{tabular}

Tabel 2. Nilai intensitas kebisingan di area kontrol dB(A) (Hari Kamis)

\begin{tabular}{|c|c|c|c|}
\hline \multirow{2}{*}{$\begin{array}{c}\text { Hari } \\
\text { Kamis } \\
\text { (Waktu) }\end{array}$} & \multicolumn{3}{|c|}{$\begin{array}{c}\text { Intensitas kebisingan rata - rata pada } \\
\text { berbagai jarak pengukuran } \mathrm{dB}(\mathrm{A})\end{array}$} \\
\hline & $\begin{array}{c}20 \mathrm{~m} \\
(\text { Plot 1) }\end{array}$ & $\begin{array}{c}40 \mathrm{~m} \\
\text { (Plot II) }\end{array}$ & $\begin{array}{c}60 \mathrm{~m} \\
\text { (Plot III) }\end{array}$ \\
\hline 07.00 & $80,9 \pm 3,8$ & $68,1 \pm 3,0$ & $62,8 \pm 4,1$ \\
\hline 10.00 & $74,5 \pm 4,0$ & $65.3 \pm 3,1$ & $59,8 \pm 3,8$ \\
\hline 17.00 & $81,9 \pm 5,8$ & $70,4 \pm 4,4$ & $65,0 \pm 5,2$ \\
\hline
\end{tabular}

Tabel 3. Nilai intensitas kebisingan di area kontrol dB(A) (Hari Sabtu)

\begin{tabular}{cccc}
\multirow{2}{*}{$\begin{array}{c}\text { Hari } \\
\text { Sabtu }\end{array}$ Waktu) } & \multicolumn{3}{c}{$\begin{array}{c}\text { Intensitas kebisingan rata - rata pada } \\
\text { berbagai jarak pengukuran dB(A) }\end{array}$} \\
\cline { 2 - 4 } & $\begin{array}{c}\mathbf{2 0} \mathbf{~ m} \\
\text { (Plot } \mathbf{1})\end{array}$ & $\begin{array}{c}\mathbf{4 0} \mathbf{~ m} \\
\text { (Plot II) }\end{array}$ & $\begin{array}{c}\mathbf{6 0} \mathbf{~ m} \\
\text { (Plot III) }\end{array}$ \\
\hline 07.00 & $78,5 \pm 5,1$ & $70,8 \pm 2,9$ & $63,4 \pm 5,1$ \\
\hline 10.00 & $78,7 \pm 5,8$ & $67,3 \pm 3,4$ & $57,9 \pm 6,3$ \\
\hline 17.00 & $76,8 \pm 4,7$ & $68,9 \pm 4,8$ & $63,5 \pm 5,8$ \\
\hline
\end{tabular}

Gambaran penurunan intensitas dapat dilihat pada gambar 1 .

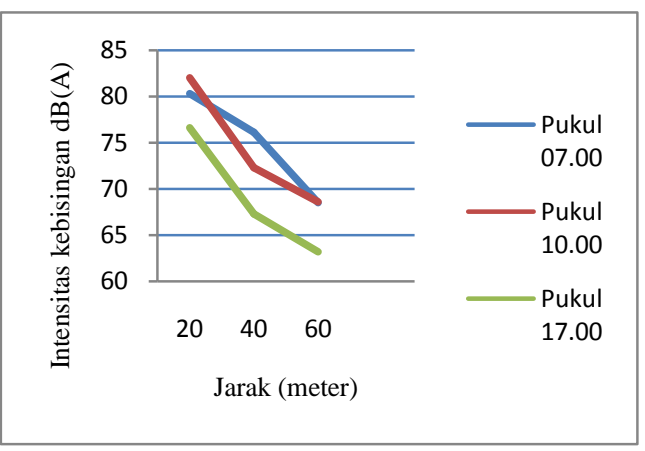

Gambar 1. Grafik penurunan intensitas kebisingan karena perbedaan jarak dari sumber kebisingan pada hari Senin

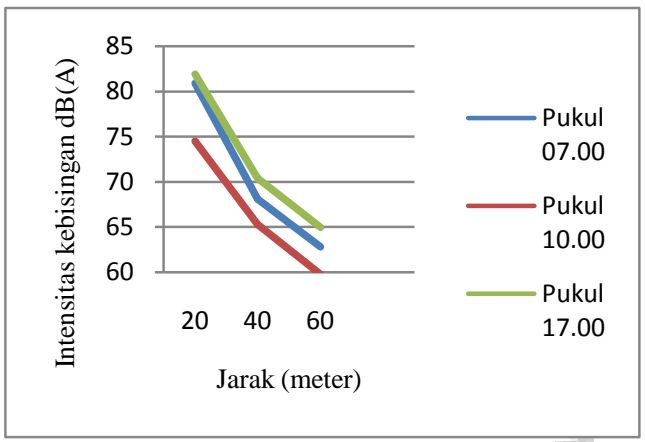

Gambar 2. Grafik penurunan intensitas kebisingan karena perbedaan jarak dari sumber kebisingan pada hari Kamis

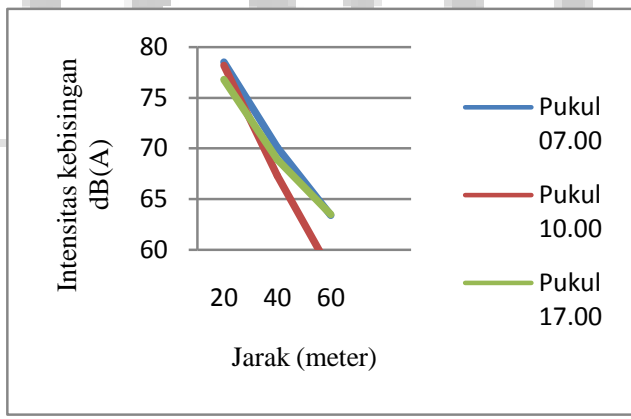

Gambar 3. Grafik penurunan intensitas kebisingan karena perbedaan jarak dari sumber kebisingan pada hari Sabtu

Dari grafik dapat dilihat bahwa kebisingan menurun dikarenakan adanya faktor jarak dengan jarak terjauh 60 meter dari sumber kebisingan dibandingkan dengan jarak terdekat dari sumber kebisingan aktivitas jalan raya, dan pada tiga hari pengukuran penurunan kebisingan relatif sama terjadi pada Pukul 17.00 sore dengan jarak 60 meter.

Penurunan intensitas kebisingan, apabila dikaitkan dengan faktor kehadiran vegetasi, tampaknya mempunyai pola tersendiri. 
Dengan vegetasi tiap - tiap plot berbeda dapat dibahas dalam kerapatan vegetasi beserta perhitungannya, yang dapat menyebabkan kebisingan juga menurun. Tiap - tiap plot yang mempunyai pengurangan intensitas kebisingan yang berbeda - beda. Untuk Pengurangan intensitas kebisingan karena faktor adanya tumbuhan dapat dilihat pada tabel.

Tabel 4. Pengurangan intensitas kebisingan karena faktor vegetasi (dBA) (Hari Senin)

\begin{tabular}{|c|c|c|c|c|c|c|c|c|c|}
\hline \multirow{3}{*}{$\begin{array}{l}\text { Hari } \\
\text { Senin } \\
\text { (Waktu) }\end{array}$} & \multicolumn{9}{|c|}{ Intensitas kebisingan rata - rata pada berbagai jarak pengukuran $\mathbf{d B}(\mathrm{A})$} \\
\hline & \multicolumn{3}{|c|}{$20 \mathrm{~m}($ Plot 1$)$} & \multicolumn{3}{|c|}{40 m (Plot II) } & \multicolumn{3}{|c|}{$60 \mathrm{~m}$ (Plot III) } \\
\hline & Kontrol & Kajian & Selisih & Kontrol & Kajian & Selisih & Kontrol & Kajian & Selisih \\
\hline 07.00 & $80,3 \pm 5,8$ & $72,3 \pm 2,5$ & $8,0 \pm 3,3$ & $76,1 \pm 2,4$ & $61,7 \pm 2,6$ & $14,4 \pm 0,2$ & $68,5 \pm 3,2$ & $43,7 \pm 2,8$ & $24,8 \pm 0,4$ \\
\hline 10.00 & $82,0 \pm 4,0$ & $73,5 \pm 3,9$ & $8,5 \pm 0,1$ & $72,3 \pm 2,9$ & $60,6 \pm 5,5$ & $11,7 \underline{ \pm 2,6}$ & $68,6 \pm 2,4$ & $58,5+4,1$ & $10,1 \pm 1,7$ \\
\hline 17.00 & $76,6 \pm 3,0$ & $57,7 \pm 4,7$ & $18,9 \pm 1,7$ & $67,3 \pm 4,4$ & $56,8 \pm 5,5$ & $10,5 \pm 1,1$ & $63,2 \pm 4,9$ & $48,3 \pm 6,3$ & $14,9 \pm 1,4$ \\
\hline
\end{tabular}

Tabel 5. Pengurangan intensitas kebisingan karena faktor vegetasi (dBA) (Hari Kamis)

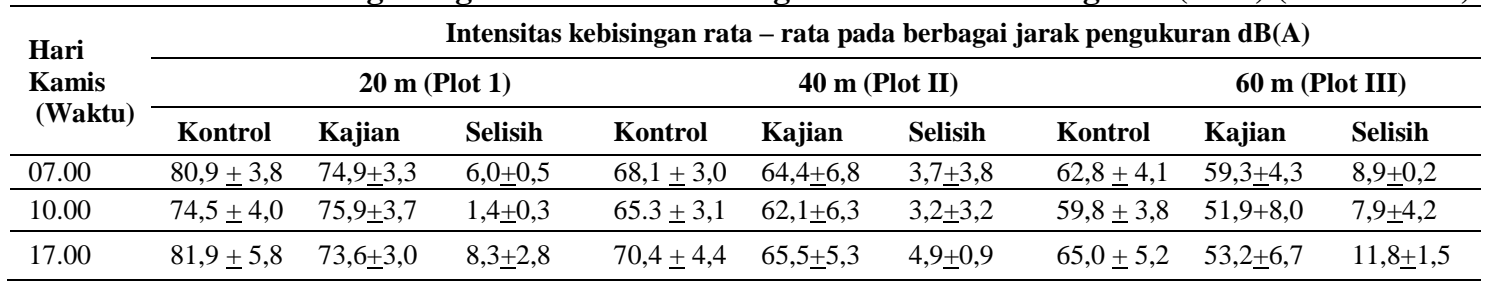

Tabel 6. Pengurangan intensitas kebisingan karena faktor vegetasi (dBA) (Hari Sabtu)

\begin{tabular}{lccccccccc}
\hline \begin{tabular}{l} 
Hari $\begin{array}{c}\text { Sabtu } \\
\text { (Waktu) }\end{array}$ \\
\cline { 2 - 11 }
\end{tabular} & \multicolumn{4}{c}{ Intensitas kebisingan rata - rata pada berbagai jarak pengukuran dB(A) } \\
\cline { 2 - 10 } & Kontrol & Kajian $($ Plot 1) & Selisih & Kontrol & Kajian & Selisih & Kontrol & Kajian & Selisih \\
\hline 07.00 & $78,5 \pm 5,1$ & $76,1 \pm 2,9$ & $2,4 \pm 2,2$ & $70,8 \pm 2,9$ & $60,5 \pm 5,0$ & $9,6 \pm 2,1$ & $63,4 \pm 5,1$ & $56,4 \pm 3,2$ & $7,0 \pm 1,9$ \\
\hline 10.00 & $78,7 \pm 5,8$ & $77,7 \pm 4,0$ & $2,5 \pm 1,8$ & $67,3 \pm 3,4$ & $61,6 \pm 5,8$ & $5,9 \pm 2,4$ & $57,9 \pm 6,3$ & $45,3 \pm 4,0$ & $14,4 \pm 2,3$ \\
\hline 17.00 & $76,8 \pm 4,7$ & $71,7 \pm 7,1$ & $4,9 \pm 2,4$ & $68,9 \pm 4,8$ & $62,5 \pm 4,7$ & $6,4 \pm 0,1$ & $63,5 \pm 5,8$ & $43,8 \pm 5,0$ & $19,7 \pm 0,3$ \\
\hline
\end{tabular}

Berdasarkan tabel diatas dapat dilihat bahwa vegetasi mempunyai kemampuan mengurangi atau meredam intensitas kebisingan berdasarkan juga pengaruh dan karena adanya perbedaan jarak juga adanya faktor vegetasi pada tiap- tiap plot pengukuran. Perbedaan tingkat penurunan kebisingan pada tiap plot dapat disebabkan vegetasi yang terdapat pada tiap plot tersebut apakah tergolong rapat atau sedang bahkan rendah yang mampu meredam kebisingan, Untuk lebih jelas, penurunan intensitas kebisingan dari tabel dapat dilihat pada gambar.

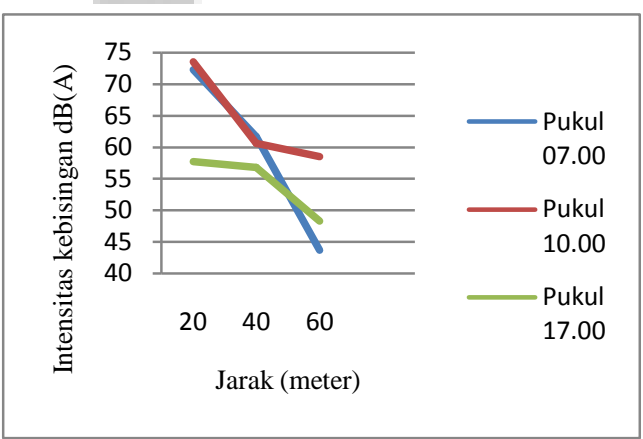

Gambar 4. Grafik penurunan intensitas kebisingan karena faktor vegetasi pada hari Senin 


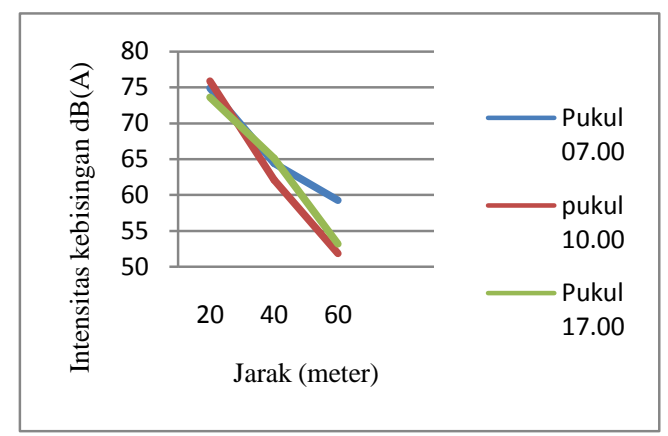

Gambar 5. Grafik penurunan intensitas kebisingan karena faktor vegetasi pada hari Kamis

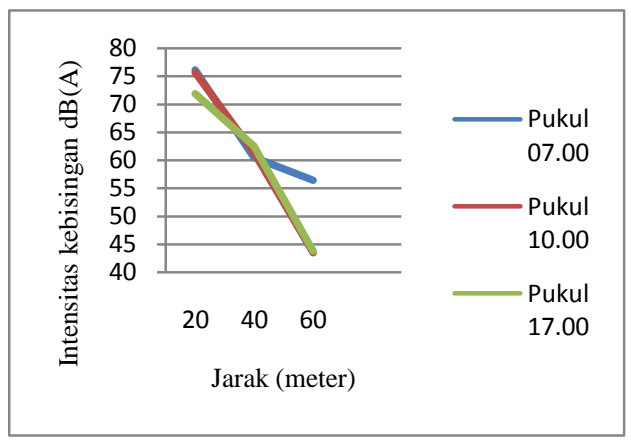

Gambar 6. Grafik penurunan intensitas kebisingan karena faktor vegetasi pada hari Sabtu

Faktor - faktor pada vegetasi yang diduga mempunyai pengaruh terhadap intensitas kebisingan kerapatan vegetasi dan tinggi batang bebas cabang. Faktor - faktor itu merupakan parameter vegetasi yang diukur pada setiap plot dan merupakan variabel independen. Sedangkan variabel dependen adalah besarnya nilai intensitas kebisingan yang terukur. Untuk mengetahui kuat lemahnya hubungan antara variabel nilai intensitas kebisingan dan variabel parameter vegetasi digunakan analisis statistik dengan uji korelasi sederhana.

Hasil analisis korelasi sederhana menghasilkan koefisien korelasi antara intensitas kebisingan dengan kerapatan vegetasi dan tinggi batang bebas cabang.

Kerapatan merupakan Nilai yang menunjukkan jumlah individu dari jenisjenis yang menjadi anggota suatu komunitas tumbuhan dalam luasan tertentu. Untuk mengitung kerapatan vegetasi dengan menggunakan rumus :

$$
\text { Kerapatan }(\mathrm{K})=\frac{\text { Jumlah individu }}{\text { Luas plot }}
$$

Pada plot 1 luas kuadran $20 \mathrm{~m} \times 20 \mathrm{~m}$ sehingga luas plot adalah $400 \mathrm{~m}^{2}$, maka kerapatan vegetasi pada plot 1 adalah 1,06. Pada plot 2 kerapatan vegetasi adalah 1,01. Dan pada plot 3 kerapatan vegetasi didapat 1,21 .

Tabel 7. Hubungan kerapatan vegetasi dengan kebisingan

\begin{tabular}{cccccc}
\hline $\begin{array}{c}\mathrm{n} \\
\text { (plot })\end{array}$ & $\mathrm{x}$ & $\mathrm{y}$ & $\mathrm{xy}$ & $\mathrm{x}^{2}$ & $\mathrm{y}^{2}$ \\
\hline 1 & 79.0 & 1.06 & 83.74 & 6241 & 1.1236 \\
\hline 2 & 69.5 & 1.01 & 70.195 & 4830.25 & 1.0201 \\
\hline 3 & 63.6 & 1.21 & 76.956 & 4044.96 & 1.4641 \\
\hline $\boldsymbol{\Sigma}$ & $\mathbf{2 1 2 . 1}$ & $\mathbf{3 . 2 8}$ & $\mathbf{2 3 0 . 8 9 1}$ & $\mathbf{1 5 1 1 6 . 2 1}$ & $\mathbf{3 . 6 0 7 8}$ \\
\hline
\end{tabular}

\section{Analisa Korelasi}

$$
\begin{aligned}
& r=\frac{n\left(\sum x y\right)-\left(\sum x\right)(\Sigma y)}{\sqrt{n\left(\sum x^{2}\right)-\left(\Sigma(x)^{2}\right.} \sqrt{n\left(\Sigma y^{2}\right)-\left(\sum y\right)^{2}}} \\
& \mathrm{r}=\mathbf{0 , 6 2 1}
\end{aligned}
$$

Pada jarak $20 \mathrm{~m}, 40 \mathrm{~m}$ dan $60 \mathrm{~m}$ hubungan antara kerapatan vegetasi dengan intensitas kebisingan mempunyai koefisien korelasi kuat dan kekuatan korelasinya kuat. Nilai koefisien determinasi sebesar 0,386. Hal ini menunjukkan kemampuan variabel kerapatan dalam mempengaruhi variabel kebisingan sebesar 38,6 \%, sedangkan sisanya sebesar $61,4 \%$ dipengaruhi oleh faktor lain.

Tinggi bebas cabang (lepas cabang atau sampai batas tajuk), yakni tinggi yang diukur titik lepas cabang atau batas tajuk dengan titik proyeksinya pada permukaan tanah.Dalam prakteknya, tidaklah mudah menentukan "bebas cabang" tersebut, karena setiap orang dapat berbeda pendapat dalam menginterpretasikannya.Oleh karena itu pada observasi dilakukan pengukuran tinggi batang bebas cabang secara manual dengan menggunakan tiang dengan ukuran panjang \pm 10 meter.

Dengan mendapatkan nilai dari tinggi batang bebas cabang pada pohon maka dapat dihitung koefisien korelasinya. 
Tabel 8. Hubungan tinggi batang bebas cabang dengan kebisingan

\begin{tabular}{cccccc}
\hline $\begin{array}{c}\mathrm{n} \\
\text { (plot) }\end{array}$ & $\mathrm{x}$ & $\mathrm{y}$ & $\mathrm{xy}$ & $\mathrm{x}^{2}$ & $\mathrm{y}^{2}$ \\
\hline 1 & 79.0 & 25 & 1975 & 6241 & 625 \\
\hline 2 & 69.5 & 15 & 1042.5 & 4830.25 & 225 \\
\hline 3 & 63.6 & 12 & 763.2 & 4044.96 & 144 \\
\hline $\boldsymbol{\Sigma}$ & $\mathbf{2 1 2 . 1}$ & $\mathbf{5 2}$ & $\mathbf{3 7 8 0 . 7}$ & $\mathbf{1 5 1 1 6 . 2 1}$ & $\mathbf{9 9 4}$ \\
\hline
\end{tabular}

Analisa Korelasi

$$
\begin{aligned}
& r=\frac{n\left(\sum x y\right)-\left(\sum x\right)\left(\sum y\right)}{\sqrt{n\left(\sum X^{2}\right)-\left(\Sigma(x)^{2}\right.} \sqrt{n\left(\Sigma y^{2}\right)-\left(\sum y\right)^{2}}} \\
& r=\mathbf{0 , 9 8 6}
\end{aligned}
$$

Pada jarak $20 \mathrm{~m}, 40 \mathrm{~m}$ dan $60 \mathrm{~m}$ hubungan antara kerapatan vegetasi dengan intensitas kebisingan mempunyai koefisien korelasi sangat kuat dan kekuatan korelasinya hampir sempurna kuat. Nilai koefisien determinasi sebesar 0,9604. Hal ini menunjukkan kemampuan variabel tinggi batang lepas cabang dalam mempengaruhi variabel kebisingan sebesar 97,2\%, sedangkan sisanya sebesar $2,8 \%$ dipengaruhi oleh faktor lain.

Kemudian menyusun persamaan regresi.Fungsi persamaan regresi ini adalah untuk membuat prediksi besarnya nilai variabel parameter vegetasi jika intensitas kebisingan sudah diketahui.Analisis regresi ganda dengan dua prediktor digunakan oleh peneliti bermaksud untuk meramalkan bagaimana keadaan variabel dependen dengan variabel independen.

Untuk menghitung harga - harga a, $b_{1}$, $\mathrm{b}_{2}$ dapat menggunakan persamaan berikut : (untuk regresi dua prediktor).

$\boldsymbol{\Sigma} \mathrm{Y}=\mathrm{an}+\mathrm{b}_{1} \boldsymbol{\Sigma} \mathrm{X}_{1}+\mathrm{b}_{2} \boldsymbol{\Sigma} \mathrm{X}_{2}$

$\Sigma \mathrm{X}_{1} \mathrm{Y}=\mathrm{a} \boldsymbol{\Sigma} \mathrm{X}_{1}+\mathrm{b}_{1} \Sigma \mathrm{X}_{1}^{2}+\mathrm{b}_{2} \Sigma \mathrm{X}_{1} \mathrm{X}_{2}$

$\boldsymbol{\Sigma} \mathrm{X}_{2} \mathrm{Y}=\mathrm{a} \boldsymbol{\Sigma} \mathrm{X}_{2}+\mathrm{b}_{1} \boldsymbol{\Sigma} \mathrm{X}_{1} \mathrm{X}_{2}+\mathrm{b}_{2} \boldsymbol{\Sigma} \mathrm{X}_{2}^{2}$ jadi :

$\mathrm{a}=58.4, \mathrm{~b}_{1}=-7.6$ dan $\mathrm{b}_{2}=-1.186$

Jadi, persamaan regresi ganda linier untuk dua prediktor (kerapatan vegetasi dan tinggi batang bebas cabang) adalah:

$$
\mathrm{Y}=58.4-7.6 \mathrm{X}_{1}-1.186 \mathrm{X}_{2}
$$

Persamaan regresi ini menunjukkan besarnya pengaruh variabel parameter tumbuhan terhadap intensitas kebisingan pada plot. Yaitu pada jarak $20 \mathrm{~m}, 40 \mathrm{~m}$ dan $60 \mathrm{~m}$, parameter vegetasi yang mempunyai kontribusi besar terhadap pengurangan intensitas kebisingan adalah kerapatan vegetasi yaitu mampu mengurangi kebisingan $7.6 \mathrm{~dB}(\mathrm{~A})$ sedangkan tinggi batang bebas cabang mampu mengurangi kebisingian sebesar $1.186 \mathrm{~dB}(\mathrm{~A})$ Hal ini menunjukkan bahwa pada kajian vegetasi sebagai peredam kebisingan harus diperhatikan variabel - variabel pada vegetasi yang mampu meredam intensitas kebisingan. Dari hasil penelitian ini faktor yang paling menentukan adalah kerapatan vegetasi dan tinggi batang bebas cabang.

Dengan melihat dari faktor lingkungan bahwa suhu, kelembapan dan kecepatan serta arah angin dapat disajikan dalam data sebagai berikut.

Tabel 9. Informasi angin lokasi Punti kayu

\begin{tabular}{|c|c|c|c|c|}
\hline \multirow[t]{2}{*}{ Tanggal } & \multicolumn{3}{|c|}{ Kecepatan angin (knot) } & Arah Angin \\
\hline & $2 \mathrm{~m}$ & $6 \mathrm{~m}$ & $10 \mathrm{~m}$ & $10 \mathrm{~m}$ \\
\hline $09 / 02 / 2015$ & 3,27 & 2,97 & 3,07 & $255^{0}$ \\
\hline $12 / 02 / 2015$ & 2,25 & 2,74 & 2,33 & $\begin{array}{c}\text { (Barat daya) } \\
229^{0} \\
\text { (Barat daya) }\end{array}$ \\
\hline $14 / 02 / 2015$ & 1,60 & 3,60 & 1,82 & $\begin{array}{c}169^{\circ} \\
\text { (Tenggara) }\end{array}$ \\
\hline
\end{tabular}
Palembang pada tanggal 09, 12 dan 14 februari

Sumber : Statiun klimatologi klas I Kenten Palembang $B M K G$

Dengan melihat informasi angin pada data yang tersaji bahwa peneliti melakukan penelitian pada ketinggian dibawah dari 2 meter, dengan melihat hasil pada informasi angin yang telah dilakukan bahwa pengukuran pada pengukuran $2 \mathrm{~m}$ tidak ditentukan arah angin begitu juga dengan ketinggian 6 $\mathrm{m}$, pada ketinggian $10 \mathrm{~m}$ saja pengukuran dapat ditentukan arah anginnya. Dengan melihat informasi suhu dan kelembapan pada data tabel berikut yang dilakukan langsung oleh peneliti. 
Tabel 10. Informasi Suhu dan Kelembapan pada Daerah Kajian (Terdapat Vegetasi) Tanggal 09 Februari 2015

\begin{tabular}{|c|c|c|c|c|c|}
\hline \multicolumn{2}{|c|}{ Plot I } & \multicolumn{2}{|c|}{ Plot II } & \multicolumn{2}{|c|}{ Plot III } \\
\hline $\begin{array}{c}\text { Suhu } \\
\left({ }^{0} \mathrm{C}\right)\end{array}$ & $\begin{array}{c}\text { Kelembapan } \\
(\text { RH\%) }\end{array}$ & $\begin{array}{c}\text { Suhu } \\
\left({ }^{0} \mathrm{C}\right)\end{array}$ & $\begin{array}{c}\text { Kelembapan } \\
(\text { RH\% })\end{array}$ & $\begin{array}{c}\text { Suhu } \\
\left({ }^{0} \mathrm{C}\right)\end{array}$ & $\begin{array}{c}\text { Kelembapan } \\
(\text { RH\%) }\end{array}$ \\
\hline 30,8 & 69,4 & 29,9 & 71,2 & 28,4 & 73,5 \\
\hline \multicolumn{6}{|c|}{ Tanggal 12 Februari 2015} \\
\hline \multicolumn{2}{|c|}{ Plot I } & \multicolumn{2}{|c|}{ Plot II } & \multicolumn{2}{|c|}{ Plot III } \\
\hline $\begin{array}{c}\text { Suhu } \\
\left({ }^{0} \mathrm{C}\right)\end{array}$ & $\begin{array}{c}\text { Kelembapan } \\
(\text { RH\%) }\end{array}$ & $\begin{array}{c}\text { Suhu } \\
\left({ }^{0} \mathrm{C}\right)\end{array}$ & $\begin{array}{c}\text { Kelembapan } \\
(\text { RH\%) }\end{array}$ & $\begin{array}{r}\text { Suhu } \\
\left({ }^{0} \mathrm{C}\right)\end{array}$ & $\begin{array}{c}\text { Kelembapan } \\
(\text { RH\%) }\end{array}$ \\
\hline 31,9 & 54,6 & 30,1 & 61,9 & 29,0 & 68,5 \\
\hline \multicolumn{6}{|c|}{ Tanggal 14 Februari 2015} \\
\hline \multicolumn{2}{|c|}{ Plot I } & \multicolumn{2}{|c|}{ Plot II } & \multicolumn{2}{|c|}{ Plot III } \\
\hline $\begin{array}{c}\text { Suhu } \\
\left({ }^{0} \mathrm{C}\right)\end{array}$ & $\begin{array}{c}\text { Kelembapan } \\
(\text { RH \%) }\end{array}$ & $\begin{array}{c}\text { Suhu } \\
\left({ }^{0} \mathrm{C}\right)\end{array}$ & $\begin{array}{c}\begin{array}{c}\text { Kelembapan } \\
(\text { RH \%) }\end{array} \\
\end{array}$ & $\begin{array}{c}\text { Suhu } \\
\left({ }^{0} \mathrm{C}\right)\end{array}$ & $\begin{array}{c}\text { Kelembapan } \\
(\text { RH\%) }\end{array}$ \\
\hline 29,7 & 59,4 & 29,2 & 70,4 & 28,0 & 74,5 \\
\hline
\end{tabular}

Setelah melakukan pengukuran pada suhu dan kelembapan pada daerah kajian pada tiap sub plot dengan pengulangan selama tiga kali (3 hari) bahwa suhu dan kelembapan memberikan pengaruh pada intensitas kebisingan. Dengan membandingkan nilai intensitas kebisingan dengan suhu dan kelembapan bahwa semakin menurunnya intensitas kebisingan maka diikuti pula dengan menurunnya juga suhu dan kelembapan.

\section{SIMPULAN}

Dari hasil analisis dan pembahasan hasil penelitian, maka dapat saya simpulkan sebagai berikut :

1. Vegetasi mampu meredam kebisingan yang ditimbulkan oleh aktivitas jalan raya sebesar paling kecil 1,4 $\mathrm{dB}(\mathrm{A})$ (yaitu pada hari Kamis, dengan jarak 20m) sampai dengan tertinggi 19,7 dB9(A) (yaitu pada hari Sabtu, dengan jarak 60m). Kemampuan meredam kebisingan dipengaruhi oleh banyak faktor, antara lain faktor parameter vegetasi. Salah satunya parameter kerapatan vegetasi mempunyai peranan, semakin tinggi kerapatan vegetasi maka semakin tinggi efektifitas peredaman kebisingan.

2. Tinggi batang bebas cabang pada vegetasi juga mempunyai peranan yang sangat penting dalam meredam kebisingan.

3. Tingkat kebisingan tertinggi untuk setiap titik pengukuran selama pengambilan data adalah Jarak $20 \mathrm{~m}: 79,0 \pm 1,0 \mathrm{dBA}$ Jarak $40 \mathrm{~m}: 69,5 \pm 2,1 \mathrm{dBA}$

Jarak $60 \mathrm{~m}: 63,6 \pm 2,8 \mathrm{dBA}$

Kebisingan lalulintas terjadi selama pengamatan adalah berkisar antara 63,6 $79.0 \mathrm{~dB}(\mathrm{~A})$ data didapat dari hasil hitung rata - rata pada intensitas kebisingan didaerah kajian, melebihi ambang batas yang dikeluarkan oleh Keputusan Kementrian Negara Lingkungan Hidup tahun 1996 yaitu $50 \mathrm{~dB}(\mathrm{~A})$ untuk lokasi Rang Terbuka Hijau (RTH).

\section{DAFTAR PUSTAKA}

Aisah, S., Tandjung, S. D., dan Hadisusanto, S.. 2002.Kajian Vegetasi Sebagai Peredam Kebisingan yang ditimbulkan Oleh Kereta Api di Kecamatan Gamping, Kabupaten Sleman, D.I Yogyakarta.Teknosains, 15 (1): 111123.

Departemen Pekerjaan Umum, Badan Litbang, Pedoman Dampak Kebisingan Akibat Lalu Lintas. 2006.

Dumanauw, J., F. 1990. Mengenal Kayu. Yogyakarta; Penerbit Kanisius.

Federal Highway Administration, 1980. Highway traffic noise: NPC library online.

http://www.nonoise.org/traffic_files/noi se_barriers/traffic.

Hadi, S. 1982. Analisis Regresi. Yogyakarta; Andi Offset.

Huboyo, H., S., Sumiati, S. 2008. Buku Ajar Pengendalian Bising. Fakultas Teknik Lingkungan, Universitas Diponegoro.

Irwan, Z., D. 1994. Peranan Bentuk dan Struktur Hutan Kota terhadap Kualitas lingkungan Kota (Studi Kasus Lokasi 
Permukiman Kota Jakarta).Bogor; Sekolah Pascasarjana, Institut Pertanian Bogor.

Irwan. 2008. Tantangan Lingkungan dan Lansekap Hutan Kota. Jakarta: PT. Bumi Aksara.

Keputusan Menteri Negara Lingkungan Hidup. KEPMENLH No. 48/ MEN LH/II 1996, Tentang Baku Tingkat Kebisingan. Jakarta.

Kusmana C., dan Istomo. 1995. Ekologi hutan. Fakultas Kehutanan, Institut Pertanian Bogor.

Mangunwijaya, J., B. 1988. Pengantar Fisika Bangunan. Jakarta; Penerbit Djambatan.
Pusat Penelitian Lingkungan Hidup. 2014. Laporan Akhir Survei Lalu Lintas 2014. Palembang

Slamet. 2003. Ruang Terbuka hijau Kota Jakarta Antara Fungsi dan Keberadaan. Laporan penelitian Hukum Lingkungan, Program Studi Ilmu Lingkunga, Universitas Indonesia, Jakarta.

Umiati Sri. 2011.Pengaruh Tata Hijau Terhadap Tingkat Kebisingan Pada Perumahan Jalan Ratulangi Makasar. Teknika 2: 12-19.

Wibisono, Y. 2008. Pengelolahan Lanskap dan Pemeliharaan Taman Kota 1 di BSD City, Tanggerang.Bogor; Program studi Arsitektur Lanskap, Fakultas Pertanian.Institut Pertanian Bogor. 